\title{
Carcinoma in situ of contralateral testis in patients with testicular germ cell cancer: study of 27 cases in 500 patients
}

\author{
HANS VON DER MAASE, MIKAEL RØRTH, SVEN WALBOM-JØRGENSEN, \\ BENT L SØRENSEN, IVAN STR ØYER CHRISTOPHERSEN, TAGE HALD, \\ GRETE KRAG JACOBSEN， JØRGEN G BERTHELSEN， NIELS E SKAKKEBÆK
}

\begin{abstract}
Carcinoma in situ in the contralateral testis was diagnosed in 27 of 500 patients $(5.4 \%)$ with unilateral testicular germ cell cancer. Eight of the 27 patients received intensive chemotherapy for spread of their initial testicular cancer. Follow up biopsy studies did not detect changes of carcinoma in situ in any of these patients, and none developed a contralateral testicular tumour (observation time 12-88 months). Of the remaining 19 patients with carcinoma in situ, seven developed contralateral testicular cancer. The estimated risk of developing invasive growth was $40 \%$ within three years and $50 \%$ within five years. None of the 473 patients without carcinoma in situ detected by screening biopsy developed contralateral testicular cancer (observation time 12.96 months). No serious complications arose from the biopsy procedures.
\end{abstract}

All patients with unilateral testicular germ cell cancer should be offered biopsy of the contralateral testis.

\section{Introduction}

Patients with unilateral germ cell cancer of the testis have an increased risk of developing a tumour in the contralateral testis. The magnitude of this risk has been reported to be between $1 \%$ and $2 \% .{ }^{12}$ These cancers are probably always preceded by carcinoma in situ. ${ }^{34}$ On the other hand, carcinoma in situ in the contralateral testis has been found in roughly $5 \%$ of patients at the time of treatment for the initial testicular cancer.

The spontaneous course of carcinoma in situ in the contralateral testis is unknown and may be influenced by the treatment given for the initial cancer. It has therefore been our policy not to perform a contralateral orchidectomy or employ other therapeutic interventions for carcinoma in situ unless invasive growth becomes apparent during follow up.

We describe the course of carcinoma in situ of the contralateral testis detected in 27 patients during screening of 500 patients with unilateral testicular germ cell cancer.

Finsen Institute, Rigshospitalet, DK-2100 Copenhagen, Denmark HANS VON DER MAASE, MD, senior registrar, department of oncology ONB MIKAEL RØRTH, MD, DRMED, chief oncologist

SVEN WALBOM-JØRGENSEN, MD, chief oncologist

BENT L SØRENSEN, MD, DRMED, chief surgeon

University Hospital, Herlev, Copenhagen

IVAN STR ØYER CHRISTOPHERSEN, $\mathrm{MD}$, chief oncologist

TAGE HALD, MD, DRMED, professor and chief urologist

University Hospital, Gentofte, Copenhagen

GRETE KRAG JACOBSEN, MD, DRMED, chief pathologist

Laboratory of Reproductive Biology, Department of Obstetrics and Gynaecology, Rigshospitalet, Copenhagen

JØRGEN G BERTHELSEN, MD, DRMED, senior registrar

NIELS E SKAKKEBAK, MD, DRMED, consultant andrologist (professor and chief paediatrician, University Hospital, Hvidovre, Copenhagen)

Correspondence and requests for reprints to: Dr von der Maase.

\section{Patients and methods}

During July 1972 to January 1985,500 patients with unilateral testicular germ cell cancer were examined for carcinoma in situ of the contralatera testis. In the first six years only one surgical department participated in the screening project, and in this period only 13 biopsy specimens were examined. Thereafter an increasing number of surgical departments participated, and since 1980 a biopsy specimen from the contralateral testis has
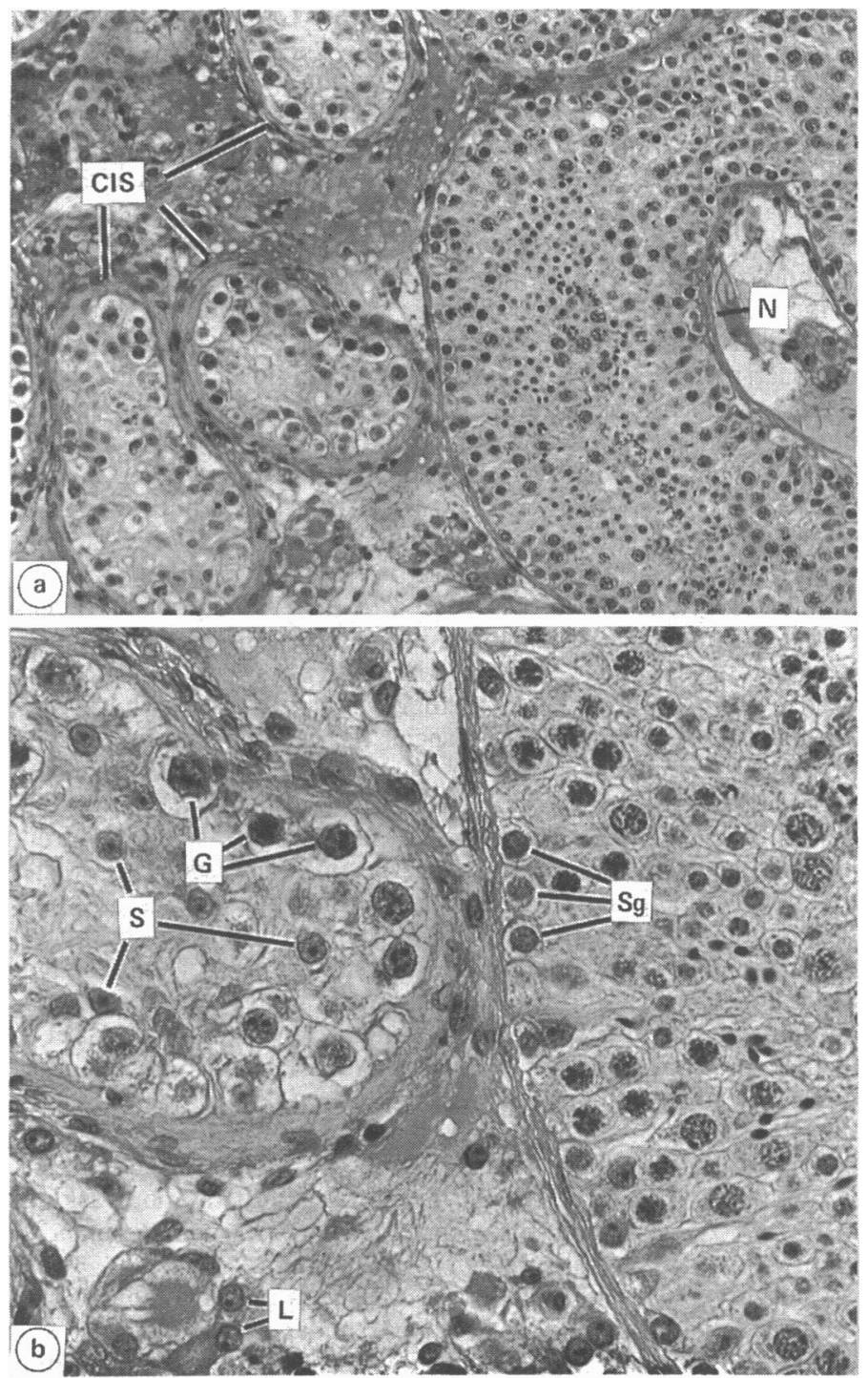

FIG 1-Carcinoma in situ of testis. (a) Section of testicular biopsy sample showing several seminiferous tubules with carcinoma in situ (CIS) and single norma tubule $(\mathbf{N})$. (b) Higher magnification of $(a)$ showing seminiferous tubules with carcinoma in situ (left) and tubule with normal spermatogenesis (right). Tubules with carcinoma in situ contained two types of cells-characteristic atypical germ cells $(G)$ and normal Sertoli cells $(S)$. Note difference between characteristic atypical germ cells and normal spermatogonia $(\mathrm{Sg})$. No invasive growth to interstitial tissue seen where normal Leydig cells $(\mathrm{L})$ present. (Cleland fixation, iron-haematoxylin and eosin.) 

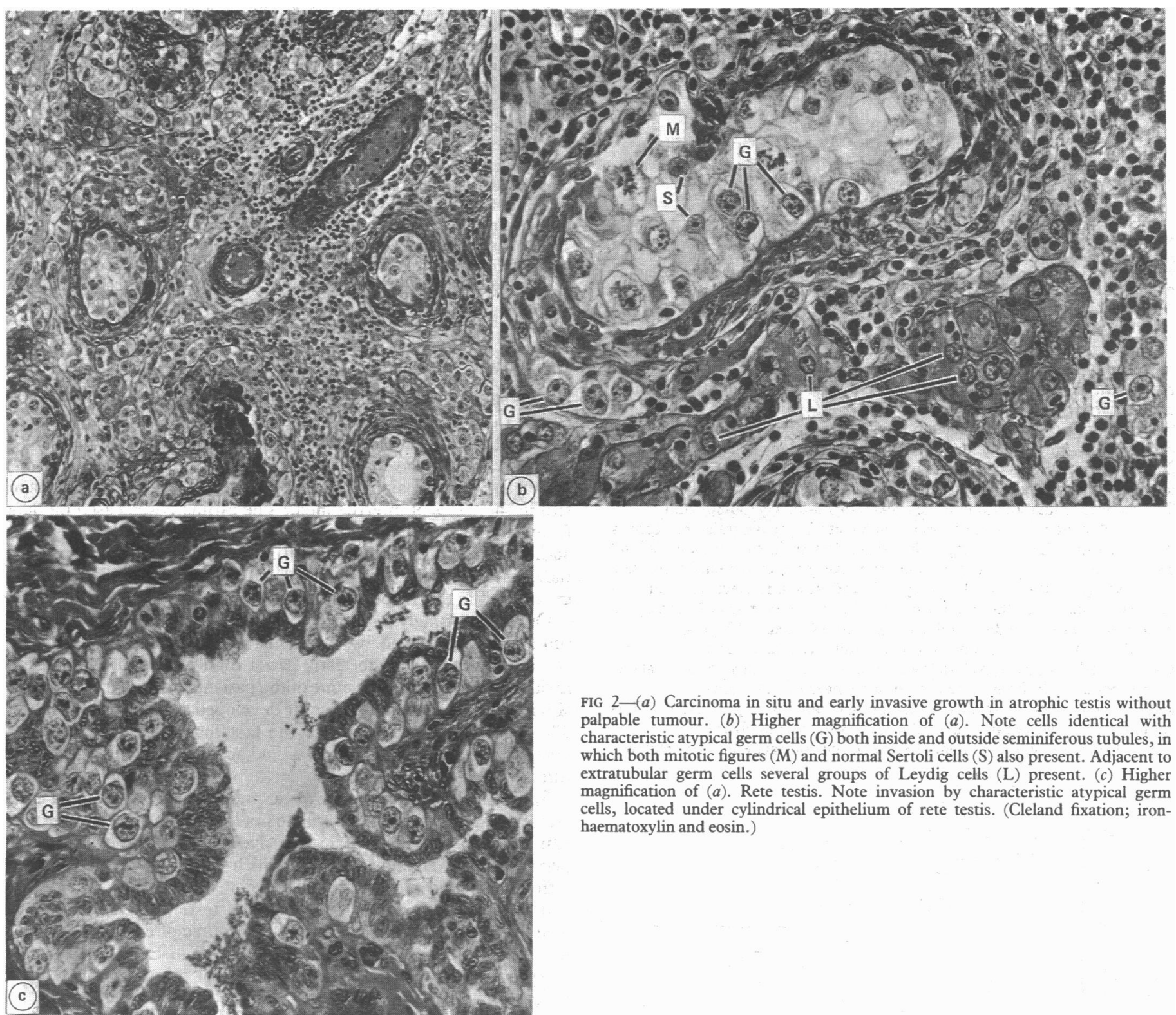

FIG 2-(a) Carcinoma in situ and early invasive growth in atrophic testis without palpable tumour (b) Higher magnification of $(a)$. Note cells identical with characteristic atypical germ cells $(G)$ both inside and outside seminiferous tubules, in which both mitotic figures $(M)$ and normal Sertoli cells $(S)$ also present. Adjacent to extratubular germ cells several groups of Leydig cells (L) present. (c) Higher magnification of $(a)$. Rete testis. Note invasion by characteristic atypical germ cells, located under cylindrical epithelium of rete testis. (Cleland fixation; ironhaematoxylin and eosin.

been examined in about $80 \%$ of all new patients in eastern Denmark with unilateral germ cell cancer. Roughly three quarters of the specimens were taken during the initial orchidectomy, the remainder being obtained at one of the two oncological centres before further treatment. All patients were observed for at least 12 months.

In all cases investigations, treatment, and follow up after orchidectomy were carried out either by the department of oncology, University Hospital, Herlev, or by the department of oncology ONB, Finsen Institute, Copenhagen. Histological classification of the tumours ${ }^{6}$ and the staging procedures $^{7}$ were performed according to the Danish testicular carcinoma study. The treatment strategy for the initial testicular cancer has been described..$^{8-10}$

Patients with carcinoma in situ of the contralateral testis were treated according to the initial testicular cancer in all respects, independently of the exact changes diagnosed. They were followed up by clinical examination of the remaining testis including measurement of the testis by an orchidometer every three months, ultrasound scanning once or twice a year, and biopsy sampling every one to two years. If invasive growth was diagnosed orchidectomy was performed and the patient resubjected to routine staging procedures.

Testicular biopsy specimens were fixed in Stieve's or Cleland's fixative, embedded in Paraplast, serially sectioned at $4 \mu \mathrm{m}$, and stained with ironhaematoxylin and eosin. Sections were examined for carcinoma in situ by light microscopy at $\times 400-1000 .{ }^{11}$ All specimens were examined by the same investigator (NES). Carcinoma in situ was defined as the presence of intratubular atypical germ cells ${ }^{12}$ (fig 1). These cells are larger than normal spermatogonia and have a large hyperchromatic nucleus containing several prominent nucleoli. The atypical germ cells are usually located in one layer close to the basement membrane, though several layers may be found. Atypical germ cells may also invade the interstitial tissue, a phenomenon denoted as early invasive growth of undifferentiated tumour cells (fig 2 ).

\section{Results}

Of the 500 patients screened, $27(5 \cdot 4 \%)$ had carcinoma in situ of the contralateral testis. Table I gives selected clinical data for these 27 patients. Characteristics such as age, histological tumour type, and distribution of staging were similar to those of patients with testicular cancer in general.

During follow up six patients developed a contralateral testicular cancer seven to 45 months after the diagnosis of carcinoma in situ, whereas one patient had early invasive growth of undifferentiated germ cell cancer adjacent to the changes of carcinoma in situ in the initial biopsy specimen. Table II gives the details of the initial and contralateral tumours. Diagnosis of contralateral testicular cancer was based on routine biopsy in three cases, detection of tumour by ultrasound in three, and growth of the testis in the remaining case. All patients were classified as having stage I disease at the time of the second orchidectomy and received no further treatment (table II). One patient developed metastases in the supraclavicular lymph nodes 36 months after the first and 15 months after the second orchidectomy. Both testicular tumours as well as the lymph node metastases were classified as pure seminomas. The patient subsequently received combina-

$\underline{0}$

$\underset{1}{3}$ 
TABLE I-Data related to initial testicular cancer in 27 patients with carcinoma in situ of contralateral testis

\begin{tabular}{|c|c|c|c|c|c|}
\hline $\begin{array}{l}\text { Histological } \\
\text { germ cell } \\
\text { tumour type }\end{array}$ & $\begin{array}{l}\text { Median age } \\
\text { in years } \\
\text { (range) }\end{array}$ & $\begin{array}{c}\text { Location } \\
\text { (right/left) }\end{array}$ & Stage & $\begin{array}{c}\text { No } \\
\text { of } \\
\text { patients }\end{array}$ & Treatment \\
\hline Seminoma & $33(26-48)$ & $8 / 8$ & $\left\{\begin{array}{l}\text { I } \\
\text { II } \\
\text { III }\end{array}\right.$ & $\begin{array}{r}13 \\
2 \\
1\end{array}$ & $\begin{array}{l}\text { Radiotherapy } \\
\text { Radiotherapy } \\
\text { Chemotherapy }\end{array}$ \\
\hline Non-seminoma & $28(24-45)$ & $4 / 7$ & $\left\{\begin{array}{l}\text { I } \\
\text { II } \\
\text { III }\end{array}\right.$ & $\begin{array}{l}6 \\
4 \\
1\end{array}$ & $\begin{array}{l}\text { Radiotherapy or observation } f \\
\text { Chemotherapy } \\
\text { Chemotherapy }\end{array}$ \\
\hline
\end{tabular}

*"Seminoma" refers to tumour consisting entirely of seminoma components; "non-seminoma" refers to all other germ cell tumour types whether seminoma component present or not. fOne patient in each group received chemotherapy at relapse after 43 and four months respectively. chemotherapy, either as primary treatment after orchidectomy (six patients) or for relapse (two). The chemotherapeutic regimen consisted of cisplatin, vinblastine, and bleomycin in seven patients and vinblastine and bleomycin in one. None of these eight patients developed contralateral cancer of the testis during follow up periods of $12,14,15,21,24,60,84$, and 88 months, respectively. Each of the eight patients had one or more biopsy specimens examined after chemotherapy, and in all cases the changes of carcinoma in situ had disappeared.

A total of 58 follow up biopsies were performed in the 27 patients (median two, range $0-7$ ). No serious complications arose from biopsy sampling, though local discomfort was usually present for several days.

Three of the 27 patients died, one from spread of the initial cancer and two from other causes (suicide and drug addiction).

The biopsy specimens did not show carcinoma in situ in 473 patients. None of these patients developed a contralateral testicular cancer during the period of observation (median 46 months, range 12-96 months).

\section{Discussion}

This study has elucidated the spontaneous course of carcinoma in situ in the contralateral testis of patients with unilateral testicular germ cell cancer. The estimated risk for untreated carcinoma in situ to progress to invasive cancer was $40 \%$ within three years and $50 \%$ within five years. A similar risk has been estimated for carcinoma in situ in the testes of infertile men. ${ }^{4}$ The estimate was based on data from patients receiving irradiation of the regional lymph nodes or no additional treatment after the initial orchidectomy. The scattered radiation dose to the testis of less than $0.8 \mathrm{~Gy}$ ( 80 rads) in the former group was, in this respect, considered insignificant.

Our data strongly support the concept that testicular germ cell tumours are preceded by carcinoma in situ. Thus patients with carcinoma in situ of the testis had a high risk of developing an invasive tumour, whereas none of the patients without carcinoma in situ in the screening biopsy sample developed a contralateral cancer. The concept also accords with the fact that carcinoma in situ is nearly always present in the tissue adjacent to testicular germ cell tumours. ${ }^{14} 15$

Spontaneous disappearance of carcinoma in situ did not occur in our series. Nevertheless, we still do not know whether carcinoma in situ invariably progresses to invasive growth. Some cases may persist in a premalignant state, which may help to explain the difference between the high incidence of carcinoma in situ $(5 \cdot 4 \%)$ and the presumed incidence of bilateral testicular cancer $(1-2 \%)$. The influence of chemotherapy on the course of carcinoma in situ may be another explanation for this apparent discrepancy. Finally, the previous reported incidence of bilateral testicular cancer may have been underestimated.

Combination chemotherapy with cisplatin, vinblastine, and bleomycin appears to eradicate carcinoma in situ. Nevertheless, a longer follow up period will be needed to show whether this effect is permanent. It should be noted that development of a contralateral cancer has occasionally been observed despite prior combination chemotherapy including regimens containing cisplatin, vinblastine, and bleomycin. ${ }^{16}$ Furthermore, we have unpublished data on four patients who developed contralateral testicular cancer after having
FIG 3- Life table ${ }^{13}$ showing relation between time after diagnosis of carcinoma in situ and proportion of patients escaping invasive growth. Estimate based on data from 19 patients not having systemic treatment and from two further patients in period up to time that they received chemotherapy for relapse of initial tumour. Fine lines represent $95 \%$ confidence limits.

TABLE II-Data from seven patients developing contralateral testicular cancer

\begin{tabular}{|c|c|c|c|c|c|c|c|c|c|}
\hline \multirow[b]{2}{*}{$\begin{array}{l}\text { Case } \\
\text { No }\end{array}$} & \multicolumn{3}{|c|}{ Initial testicular cancer } & \multirow{2}{*}{$\begin{array}{l}\text { Time from diagnosis of } \\
\text { carcinoma in situ to } \\
\text { invasive growth } \\
\text { (months) }\end{array}$} & \multicolumn{3}{|c|}{ Contralateral testicular cancer } & \multirow{2}{*}{$\begin{array}{c}\text { Observation } \\
\text { time from } \\
\text { second orchidectomy } \\
\text { (months) }\end{array}$} & \multirow[b]{2}{*}{$\begin{array}{l}\text { Present } \\
\text { state }\end{array}$} \\
\hline & $\begin{array}{l}\text { Histological } \\
\text { type }\end{array}$ & Stage & $\begin{array}{l}\text { Postorchidectomy } \\
\text { treatment }\end{array}$ & & $\begin{array}{l}\text { Histological } \\
\text { type }\end{array}$ & Stage & $\begin{array}{l}\text { Postorchidectomy } \\
\text { treatment }\end{array}$ & & \\
\hline 1 & Seminoma & I & Radiotherapy & 45 & Early invasive growth & I & None & 102 & Alive. NED $†$ \\
\hline 7 & Seminoma & I & Radiotherapy & 21 & Seminoma & I & None $\star^{\star}$ & 57 & Alive. NED \\
\hline 12 & Seminoma & I & Radiotherapy & 13 & Seminoma & I & None & 30 & Alive. NED \\
\hline 13 & Seminoma & II & Radiotherapy & 27 & Early invasive growth & I & None & 16 & Alive. NED \\
\hline 15 & Seminoma & I & Radiotherapy & 12 & Seminoma & I & None & 6 & Dead. NED $\ddagger$ \\
\hline 16 & $\begin{array}{l}\text { Embryonal carcinoma + teratoma }+ \\
\text { endodermal sinus tumour }\end{array}$ & I & Radiotherapy & 7 & Seminoma + embryonal carcinoma & I & None & 32 & Alive. NED \\
\hline 17 & Seminoma & I & Radiotherapy & 0 & Seminoma & I & None & 35 & Alive. NED \\
\hline
\end{tabular}

ॠ This patient received chemotherapy 15 months later because of supraclavicular lymph node metastases. 
received bleomycin and vincristine simultaneously with irradiation. These patients were treated according to an early protocol of the Danish testicular carcinoma study for non-seminoma stage $I,{ }^{9}$ before establishment of the screening procedure for carcinoma in situ in the contralateral testis. Thus, though we have no information about changes of carcinoma in situ before treatment of these four patients, this chemotherapeutic regimen is probably not enough to eradicate carcinoma in situ of the testis. On the other hand, intensive chemotherapy with all three agents is too toxic for the treatment of premalignant disease. Hence chemotherapy should be given only in accordance with the classification of the initial testicular cancer and not for carcinoma in situ of the contralateral testis.

None of our patients died as a result of progression of the carcinoma in situ. All patients developing cancer of the contralateral testis appeared to have been cured by orchidectomy alone. One patient developed metastases in supraclavicular lymph nodes 15 months after the second orchidectomy but it was impossible to determine whether this was relapse related to the initial or to the second testicular cancer.

It appears that patients receiving chemotherapy for the initial testicular cancer have a minimal risk of developing a contralateral tumour. These patients should be offered continuous clinical observation, including follow up biopsies, without any further treatment. Patients with carcinoma in situ not receiving chemotherapy have a high risk of developing a contralateral cancer. For these patients it is important to devise an effective and at the same time acceptable treatment for the changes of carcinoma in situ in order to avoid a second orchidectomy and subsequent androgen insufficiency. We are investigating the efficacy of localised irradiation of the testis, and our preliminary results show that a dose of $20 \mathrm{~Gy}$ (2000 rads) given over 10 days may eradicate carcinoma in situ of the testis without appreciably affecting Leydig cell function. ${ }^{17}$

In conclusion, our findings show the importance of performing a biopsy of the contralateral testis in patients with testicular cancer. If the biopsy specimen is without carcinoma in situ the patient may be assured that the risk of developing a contralateral cancer is extremely small. If carcinoma in situ is present it is possible to diagnose invasive growth at an early stage by a suitable follow up programme to eradicate the changes of carcinoma in situ and avoid invasive growth. We therefore recommend that all patients with unilateral testicular germ cell cancer should be offered a contralateral testicular biopsy.

This work was supported by the Danish Cancer Society, grant Nos 84007, 86065,86017 , and 86044 .

\section{References}

1 Pugh RCB, ed. Pathology of the testis. Oxford: Blackwell Scientific Publications, 1976. 2 Sokal M, Peckham MJ, Hendry WF. Bilateral germ cell tumours of the testis. Br $\mathcal{F}$ Urol $1980 ; 52: 158-62$.

3 Skakkebæk NE. Possible carcinoma in situ of the testis. Lancet 1972;ii:516-7.

4 Skakkebæk NE, Berthelsen JG, Muller J. Carcinoma in-situ of the undescended testis. Urol Clin North Am 1982;9:377-85.

5 Berthelsen JG, Skakkebæk NE, von der Maase H, Sørensen BL, Mogensen P. Screening for carcinoma in situ of the contralateral testis in patients with germinal testicular cancer. BrMed $\mathcal{J}$ 1982;285:1683-6.

6 Jacobsen GK, Barlebo H, Olsen J, et al. Testicular germ cell tumours in Denmark 1976-1980pathology of 1058 consecutive cases. Acta Radiol Oncol 1984:23:239-47.

Schultz HP, Arends J, Barlebo H, et al. Testicular carcinoma in Denmark 1976-1980-stage and selected clinical parameters at presentation. Acta Radiol Oncol 1984;23:249-53.

8 Schultz HP, von der Maase H, Rørth M, et al. Testicular seminoma in Denmark 1976-1980results of treatment. Acta Radiol Oncol 1984;23:263-70.

9 von der Maase H, Engelholm SA, Rorth M, et al. Non-seminomatous testicular germ cell tumours in Denmark 1976-1980 - results of treatment. Acta Radiol Oncol 1984;23:255-61

10 Rørth M, von der Maase H, Sandberg Nielsen E, Schultz HP, Svennekjær IL. Nonseminomatous testicular germ cell tumours-preliminary analysis of ongoing trials in the DATECA study. Acta Radiol Oncol 1984;23:295-304.

11 Berthelsen JG, Skakkebæk NE, Mogensen P, Sorensen BL. Incidence of carcinoma in situ of germ cells in contralateral testis of men with testicular tumours. Br Med 7 1979;ii:363-4.

12 Skakkebæk NE. Carcinoma in situ of the testis: frequency and relationship to invasive germ cell umours in infertile men. Histopathology 1978:2:157-70.

13 Peto $R$, Pike MC, Armitage $\mathbf{P}$, et al. Design and analysis of randomized clinical trials requiring prolonged observation of each patient. Br f Cancer 1977;35:1-39.

14 prolonged observation of Pach patient. Brf Cance 1977;35:1-39. Pathologica et Microbiologica Scandinavica 1975;83:A127-30.

15 Jacobsen GK, Henriksen OB, von der Maase $\mathrm{H}$. Carcinoma in situ of testicular tissue adjacent to

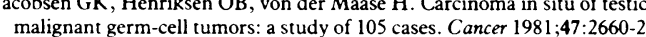

16 Fowler JE Jr, Vugrin D, Cvitkovic E, Whitmore WF Jr. Sequential bilateral germ cell tumors of Fowler JE Jr, Vugrin D, Cvitkovic E, Whitmore WF Jr. Sequentia.

17 von der Maase H, Givercman A, Skakkebæk NE. Radiation treatment of carcinoma-in-situ of testis. Lancet 1986; ; $624-5$.

\title{
Cryptorchidism: an apparent substantial increase since 1960
}

\author{
JOHN RADCLIFFE HOSPITAL CRYPTORCHIDISM STUDY GROUP
}

\begin{abstract}
A total of 1849 boys born to mothers resident in a defined area around Oxford were examined for cryptorchidism. Those born in hospital were examined at birth and again after three months
\end{abstract}

\section{John Radcliffe Hospital Cryptorchidism Study Group}

IMPERIAL CANCER RESEARCH FUND CANCER EPIDEMIOLOGY UNIT, RADCLIFFE INFIRMARY, OXFORD

Pat Ansell, SRN; Jean Barton, SRN; Diana Bull; M B Jackson, MrCGP; Anne Pike, RN; M C Pike, PHD

INSTITUTE OF CANCER RESEARCH, SUTTON, SURREY

Clair Chilvers, MSC

JOHN RADCLIFFE HOSPITAL, HEADINGTON, OXFORD

N E Dudley, FRCs; M H Gough, MS; D M Griffiths, FRCS; C Redman, FRCP; A R Wilkinson, FRCP

OXFORDSHIRE AREA HEALTH AUTHORITY, RADCLIFFE INFIRMARY, OXFORD

A Macfarlane, FRCP

Report prepared by M B Jackson, Clair Chilvers, M C Pike, Pat Ansell, Diana Bul

Correspondence to: Dr M C Pike, ICRF Cancer Epidemiology Unit, Radcliffe Infirmary, Oxford if cryptorchid at the earlier examination. The incidence of cryptorchidism at three months adjusted to the birthweight distribution of England and Wales was $1 \cdot 58 \%$. By comparison, in a very similar study conducted around 1960 the incidence was $0.96 \%$. Hence the cryptorchidism rate had apparently increased by $65 \%$ over the two decades, which contrasted with the twofold increase in the national orchidopexy rate. The proportion of boys undergoing orchidopexy appeared consistently to be roughly twice the proportion of boys with an undescended testis at 3 months of age.

The increase in cryptorchidism and disparity with the rate of orchidopexy are not easily explained and are the subjects of continuing study.

\section{Introduction}

Cryptorchidism is an important and the only well established risk factor for testicular cancer, some $10 \%$ of patients with testicular cancer having a history of the condition. ${ }^{1}$ Moreover, this frequency of past cryptorchidism among patients with testicular cancer appears to have changed little, if at all, over the past 50 years, which 